\title{
The adoption of green manure processes applied to vegetable cultivation systems in mountainous environments of Rio de Janeiro State, Brazil
}

https://doi.org/10.1515/opag-2019-0042

received April 12, 2017; accepted June 4, 2019

\begin{abstract}
The aim of the current article is to analyze the construction process of participative agroecological knowledge in the mountainous region of Rio de Janeiro State, Brazil. The challenges resulting from the climate-related natural disaster- extreme event with heavy rains - that has affected the region in January 2011 were herein highlighted. Local data, a literature review and semi-structured interviews, conducted with participants from the study area, as well as a focus group involving key people, were used to observe social behaviors. Strategies aimed at expanding the adoption of agroecological practices, mainly the practices concerning the use of cover crops, were proposed. The need to adapt to farmers' time and aspirations, inherent in the technological stage of each farmer, such as the economic gains resulting from the agroecological transition, was shown in the current study.
\end{abstract}

Keywords: Agroecology; Production systems; Cover crops

\footnotetext{
*Corresponding author: Adriana Maria de Aquino, Embrapa Agrobiology, Ministry of Agriculture and Livestock, Nova Friburgo, CEP 28621450, Brazil, Carlos da Silveira Carneiro, 44. Cascatinha. Nova Friburgo, RJ. Brazil. CEP 28621450, E-mail: adriana.aquino@ embrapa.br

Gerson José Yunes Antonio, EMATER-RIO, Rio de Janeiro State Department of Agriculture and Livestock, Nova Friburgo, CEP 28613001, Brazil

Renato Linhares de Assis, Embrapa Agrobiology, Ministry of Agriculture and Livestock, Nova Friburgo, CEP 28621450, Brazil

Alessandro Melo Rifan, UFRRJ, Ministry of Education, Seropédica, CEP 23897000, Brazil

Maria Clara Estoducto Pinto, UERJ, Ministry of Education, Maracanã, CEP 20550-900, Brazil
}

\section{Introduction}

The mountainous region is the most important agricultural production center in Rio de Janeiro State with the main activities in the region comprised of olericulture, flower crops, poultry, fruit production, dairy cattle and coffee crops. However, the region is also one of the most vulnerable in the state. The pressure caused by the accelerated population growth in the area, the mountainous terrain, as well as the uncontrolled land use and occupation, associated with the intensive use of agrochemicals in farming systems, make its forest fragments highly vulnerable and relevant for conservation purposes (Fidalgo et al. 2008). Campo do Coelho District, in Nova Friburgo County (Figure 1), was one of the most affected by landslides and floods during this natural event. The rural area recorded significant agricultural losses after the climate-related natural disaster in 2011. More than $60 \%$ of the affected areas used to be covered by olericulture. It is estimated that the loss of areas focused on this activity has exceeded 1,500 hectares; Rio de Janeiro State Department of Agriculture and Livestock, SEAPEC-RJ (2011), has estimated that 1,400 ha experienced superficial laminar erosion and that as a result 900 ha of gullies have been formed.

Agroecology takes the challenge of finding strategies that allow understanding agriculture as the co-evolution between culture and natural environment, according to a historical perspective, in order to maintain or recover the original balance, regardless of the conservation state of the agroecosystem in question (Borba and Trindade 2011). Agroecology does not intend to eliminate human intervention in ecosystems, but to understand the inherent complexity of it, which requires a systemic analysis to be conducted and the adoption of a holistic approach (Borba and Trindade 2011).

The decision-making process concerning changes in the production strategies applied to cultivation systems undergoes a collective reflection process, since "no one 


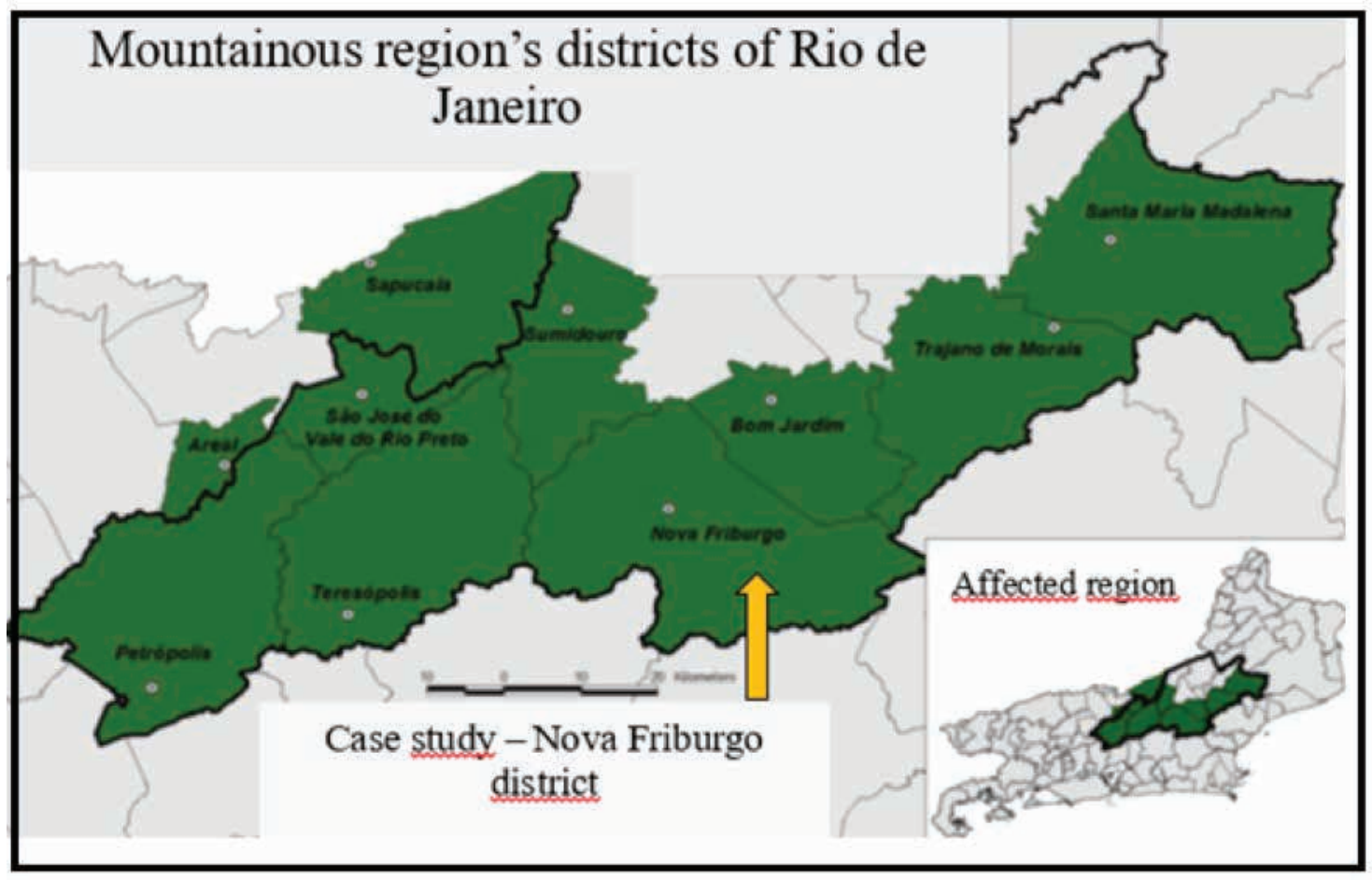

Figure 1: Mountainous region's districts of Rio de Janeiro (SEAPEC-RJ, 2011)

educates anyone any more, nor does anyone educate oneself: men educate themselves in communion, mediatized by the world" (Freire 1987). Vygotsky (1999) follows a complementary path and states that learning is a cognitive process, whereas development takes place through social interaction; thus, it meets the social nature of agroecology.

A case study by Grisel and Assis (2012) about the representative horticultural production systems in the mountainous environment of Nova Friburgo County provided important information to the understanding about the obstacles faced at the adoption of alternative practices and about the agronomic conditions appropriate to the integration of new practices. The main obstacles were the agricultural intensification restricting crop-fallow rotations due to external factors (increased number of crops to minimize the economic risk), and the socioeconomic reasons for the non-expansion due to internal factors (difficulty by the sharecropper/owner to decide what to plant and low land availability). According to the aforementioned authors, new ecological-process valuation practices must undergo gradual dissemination and assimilation processes.

According to the farmers, the main reason for using cover crops is to recover the production capacity of depleted soils, mainly in the region where the soil underwent excess of use due to the climate-related tragedy in 2011. This natural event has strongly changed the physi- cal, chemical and biological conditions of the soil in the area (Assis et al. 2012).

According to the perspective of agroecological transition processes, the replacement of the inputs used in conventional agriculture by inputs recommended to organic agriculture should be understood as a first step. Thus, it should not be the target when one pursues sustainability in its different environmental, social and economic dimensions. A process-based agriculture should be pursued by intensifying the ecosystem's natural functions; thus, the relevance of green manure must be understood according to the herein addressed context (Ambrosano et al. 2014).

The aim of the current study was to approach strategies able to improve the awareness of family farmers about the use of green manure as a cover crop in order to implement no-tillage vegetable cultures in their production systems, which may subsequently increase the possibility of adoption other agroecological practices.

\section{Methods}

The current research was of qualitative nature and used an inductive method comprising the following stages: observation, record of facts, analysis and classification, and the inductive derivation from generalizations based on facts. The literature review collected information about 
the mountainous region of Rio de Janeiro State and about the climate-related tragedy that happened in January 2011. The natural event resulted from the combination of heavy rains and the vulnerability of this mountainous environment.

Individual interviews and a focus group were the methods used in the field research to collect data used to investigate specific situations and to provide evidence for theoretical support.

Some farmers were selected for the interview in such a way that it was possible to understand the reasons for the adoption of green manure as a cover crop, since this practice is related to the first step of the agroecological transition process (Gliessman1997). There was strong adhesion to the green manure practice in Barracão dos Mendes microbasin, Nova Friburgo County, (Figure 2) the study site, according to the Research and Training Center for Farmers (NPTA - Núcleo de Pesquisa e Treinamento para Agricultores) of the Brazilian Agricultural Research Corporation - NPTA / Embrapa ${ }^{1}$, mainly to the use of black oat (Avenastrigosa).Thirty-six farmers were suggested, by local leaders, to participate in the interviews. They were chosen according to the following requirements: a) 12 farmers who have had contact with NPTA/Embrapa and adopted the green manuring process using black oat; $b$ ) 12 farmers who have not had direct contact with NPTA/ Embrapa and adopted the green manuring process using black oat; and c) 12 farmers who have not adopted the green manuring process using black oat, regardless of previous contacts with NPTA/Embrapa.

The questions asked by the interviewers followed a semi-structured questionnaire script and, whenever necessary, the questions were explained to the interviewees in order to make sure about the quality of their answers, as well as to allow the clear understanding about the farmers' experience in the agricultural practice in question. Topics addressed in the interviews comprised of mountain agriculture, the 2011 storm, the appropriation of agroecological practices (black oat, green manuring, no-tillage), family farming, marketing, awareness, participation and motivation.

1 The Research and Training Center for Farmers (NPTA) was inaugurated in 2007 after negotiations between Nova Friburgo City Hall and the Brazilian Agricultural Research Corporation (Embrapa). It had the aim to create conditions for the adaptation and dissemination of knowledge and agroecological-based technologies appropriate to the reality of mountainous environments in the Rio de Janeiro State Mountainous Region. Accordingly, the center has been acting based on the identification of demands for research actions to help the local production systems advance the agroecological transition.
On the other hand, the focus group is a methodology used to gather information from informal discussion groups comprising a small number of people (at most 12). The main aim of conducting the focus group in the current study was to observe social behaviors based on the perspective of technicians and farmers working in the region, through the confrontation of opinions, in order to clarify and help understanding issues related to the agroecological transition, as well as to contribute to the development of strategies aimed at expanding the adoption of agroecological practices. The focus group conducted during the present study comprised eight participants (six technicians and two farmers) and covered the following topics: how the agroecological transition process was implemented; the benefits from and the barriers to the agroecological transition in family production systems; the identification of well-accepted agroecological practices; and the prerequisites for the transition-process adoption and its challenges.

Ethical approval: The conducted research is not related to either human or animal use.

\section{Results and discussion}

The reasons listed by the interviewed farmers to justify the adoption of black oat as green manure were the good performance, due to its influence on soil recovery and capacity to improve production; and the black oat's easy cultivation and adaptability. Since the plant is rustic and has a short growth cycle, it reduces the competition with weeds. Besides, the black oat has potential to reduce erosion by keeping the soil covered for longer, which avoids landslides; as well as to decrease the use of inputs, since black oat reduces the demand for agrochemicals, which in turn reduces production costs.

The contribution to soil recovery was the main disseminating aspect of the green manuring technique using black oat. This species has adapted very well to the lesser production periods and to the greater availability of fallow lands since it is a winter crop.

The soil quality improvement was strongly perceived by the farmers through root structuring; organic matter incorporation; increased soil 'softness'; through the presence of beneficial invertebrates; the activation of soil microorganisms; nutrient transportation from the lowest layers to the most superficial part of the soil; soil moisture maintenance with consequent irrigation savings; and through improved drainage in crop areas. The increased 


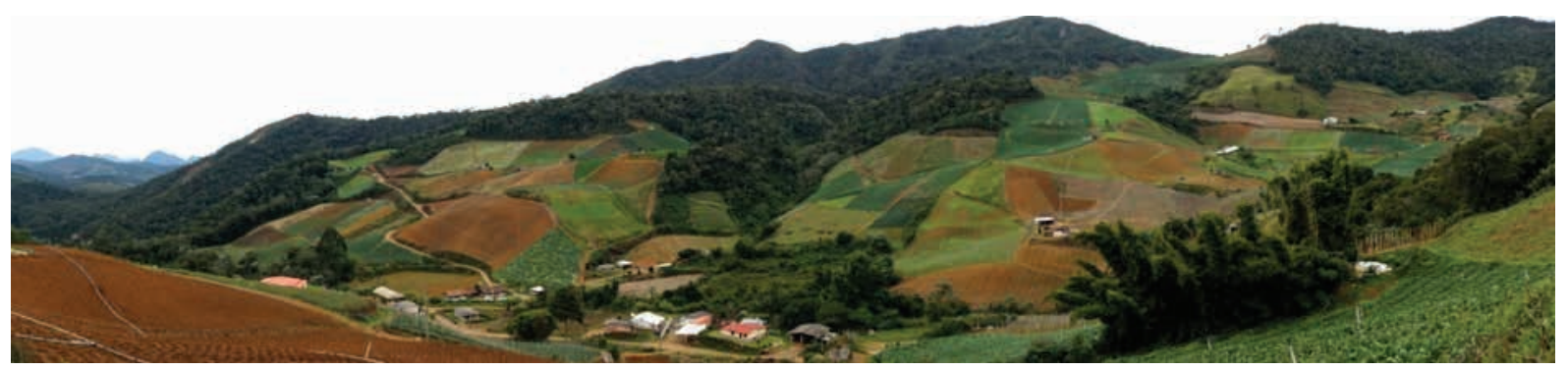

Figure 2: Barracão dos Mendes micro basin’s landscape, Nova Friburgo County (Photograph: Alessandro Rifan)

Table 1: Green manuring practice strategies

\section{Practice strategies}

Cultural sequence of Green Manure

\begin{tabular}{|c|c|c|c|c|c|}
\hline 1)PSISDNT & Plowing & Sow & oat dried & straw not incorporated & No-tillage \\
\hline 2)PSISNDNT & Plowing & Sow & oat not dried & straw not incorporated & No-tillage \\
\hline 3) PSNISDIS & Plowing & Sow & oat dried & straw incorporated & Tillage \\
\hline 4) PSNISNDIS & Plowing & Sow & oat not dried & straw incorporated & Tillage \\
\hline
\end{tabular}

productivity and quality of products treated through the green manuring technique was highlighted by the farmers. They also noticed the green manuring reducing effects on pests and diseases, mainly the reduced incidence of clubroot of crucifers, which is often found in cauliflower plantations in the region.

The climate event that has led to an environmental tragedy in the region, in January 2011, has also influenced the acceptance of the green manuring practice using oats. At that time, rural development agents working in the region encouraged the use of black oats as cover crop in the region, in a strategic and institutional way. It was done to provide agricultural recovery alternatives for areas such as sloped areas affected by mudslides and landslides, and lowland areas leached due to flooding (Antonio et al. 2016).

The perception about climate changes after the tragedy, mainly about the mismatch between seasons and the decreased flow in water bodies, triggered behavioral changes. Fourteen out of the 36 interviewed farmers (39\%) have mentioned that the post-tragedy experience made them reason about the need of adapting to climate changes; $58 \%$ of the farmers started adapting the crops to climate changes by postponing or anticipating the planting season; $64 \%$ of the farmers have adopted the green manure technique using black oat.

The interviews conducted with the 24 farmers who used the green manure technique, as well as the direct observation in the field, showed that the aspects related to the soil quality improvement resulting from black oat use in vegetable cultivation rotations applied to local crop systems, were the most perceived by the farmers (Table 1).

The understanding about the adoption of the green manure technique using black oat by farmers was analyzed according to the following aspects: a) planting method; b) cultivation method; c) the use other green manure species; d) green manure cultivation period; and e) number of commercial planting cycles throughout the year. Two planting methods were performed as follows: according to 18 farmers, the land is plowed, the black oat is spread sown, and the seeds are incorporated into the soil through the preparation of seedbeds or planting pits to cultivate vegetables in succession (PSI); according to 6 farmers, the land is plowed, the black oat is spread sown, and the seeds are not incorporated into the soil (PSNI).

As for the green manure cultivation, 22 respondents used herbicide to burn the black oat, and 2 respondents



Figure 3: No-tillage, straw not incorporated, identified with X (Photograph: Renato Assis) 
did not use it. Thus, four green manuring practice strategies were identified, as can be seen below.

Most farmers adopted the cultivation technique based on the black oat desiccation using herbicide and incorporated the green manure straw (3- PSNISDIS) into the soil or not (1- PSISDNT) (Figure 3). The no-tillage was an innovation the farmers added to the cultivation process and it has positively affected the soil conservation.

Some farmers have innovated by adapting the technology to the conditions found in their production systems in order not to use herbicide to dry the oat, thus setting the cultivations identified as 4- PSNISNDIS and 2PSISNDNT. In the first case, they incorporated the straw into the soil; as for the second case, they left the straw on the soil surface, thus adopting the no-tillage practice.

Most farmers (21) made the option for using black oat as green manure due to the easy access to its seeds in the local input market and to its better adaptability to the region. They also mentioned that they anticipated or extended the planting season beyond winter, i.e., they planted from March to January.

In addition, the farmers' perception about mountainous environments was associated with the natural resources making the agricultural production feasible or unfeasible, because this is how farmers can manage the environment-productivity relation in a more (or less) efficient way. Among the aspects related to the interviewed farmers' perception about mountainous environments, it is worth highlighting that 22 farmers have mentioned the possibility of cultivating different crops adequate to the local edaphoclimatic conditions. Nine farmers have also associated mountainous environments with spaces showing higher availability of quality water; whereas eight respondents have associated mountainous environments with strongly sloped areas that hinder cultivation and locomotion, and that are vulnerable to environmental catastrophes.

The agroecological transition may be defined as a gradual, continuous and multilinear changing process applied to agroecosystem-cultivation forms (Costabeber 2006). The purpose is to move from the current rural development patterns or from low-sustainability production systems to agricultural and rural cultivation models that privilege and incorporate ecologically-based principles, methods and technologies. This approach implies changing the attitudes and values of social actors towards resource management and conservation, along with the pursuit of greater productive rationalization based on the specificities of each agroecosystem. The specific features of agroecological transition processes point out to a set of conditions necessary for the implemented technical and organizational innovations. These processes effectively promote structural changes for the benefit of the farming families in particular and of society in general (Costabeber 2006).

Therefore, it is necessary to perceive and identify the determining factors for the adoption of practices aimed at agroecological transition through the use of cover crops in production systems run by family owned farms (Antonio et al., 2016). It is also necessary to take into consideration all the territory potentialities and local dynamics, mainly in the agricultural sector, in order to understand and propose guidelines containing course corrections as a way to make it possible broadening the appropriation by social actors.

Accordingly, the focus group results made it clear that: a) the transition to a more sustainable agricultural model depends on the joint work of two very different groups, namely: technicians and farmers; b) farmers demand less transition than technicians. Thus, technicians should get adapted to farmers'reality, not the opposite; c) farmers seem to be more focused on others (the consumer, the market) than on themselves. Yet, consumers do not trigger changes in this system, because the consumer market for organic products remains restricted. d) the challenge lies in providing farmers with clear and simple calculations to compare systems (traditional $\mathrm{x}$ agroecological), economies and profits resulting from the agroecological transition. It is important on making farmers aware of other benefits from this new production form, such as better health, greater autonomy, more egalitarian family relations, among others.

\section{Recommendations and conclusions}

The current study has shown that the tragedy has contributed to direction changes. It also reinforced the idea that the capacity to leverage these potentials and to boost the territory formed by mountainous environments in Rio de Janeiro State mountain region requires innovative institutional arrangements to connect populations living in the area in question, as well as to promote crucial collective actions to the agroecological strategies adopted to design agricultural systems resilient to climate changes.

The strategies aimed at increasing the adoption of agroecological practices in family production systems in this mountainous environment should acknowledge the need to improve the efforts by the institutions and to adapt 
to farmers' time and needs in order to get to accomplish economic gains resulting from agroecological transition.

The path to increase the farmers' protagonism and conscious participation in the formation of a social capital depends on three lessons learned from the herein exposed: i) the proposed innovations should be based on practices already accepted by the farmers, as it was shown in the use of black oat as cover crop; however, it is necessary going further and advancing the development of participatory knowledge construction processes aimed at agroecological transitions to assure the effective agricultural production sustainability in mountainous environments;ii) it is necessary expanding the sociotechnical network beyond the traditional actors primarily linked to public research and the rural extension institutions, in order to achieve independent and efficient results in innovation processes adequate to the socio-environmental reality of the local mountainous spaces; iii) the understanding of the agroecosystem as a knowledge-organization space, in its ecological and socioeconomic relations, must be approached from a systemic perspective increasingly focused on encouraging social technological innovation processes, mainly through experimentation.

This manuscript may be an interesting account of decision making processes and can have implications for a wider community. The impact of this research is relevant to other areas of mountain agriculture contributing to the appropriation of agroecological practices.

Conflict of interest: Authors declare no conflict of interest.

\section{References}

[1] Antonio G.J.Y., Assis R.L., Aquino A.M., Experience of agroecologic transition using cover crop in family production systems at the hills environment of Rio de Janeiro State - Brazil, In: I International Conference on Research for Sustainable Development in Mountain Regions: Book of Abstracts.Bragança, Portugal, 2016, 182

[2] Assis R.L., Madeira N., Aquino A.M., Teixeira O., Pereira M.S., Guerra J.G.M., Risso I.A., Experiências e estratégias na inserção da adubação verde em sistemas de cultivo de hortaliças na Região Serrana Fluminense, Circular Técnica 32, Embrapa Agrobiologia, Seropédica, RJ, 2012 (in Portuguese)

[3] Ambrosano E.J., Rossi F., Guirado N., Schammass E.A., Muraoka T., Trivelin P.C.O., Ambrosano G.M.B., Adubação verde na agricultura orgânica, In: LIMA FILHO, O. F. et. al., Adubação verde e plantas de cobertura no Brasil: fundamentos e prática, vol. 2, 2014, Embrapa, Brasília - DF, 2014,47 (in Portuguese)

[4] Borba M.F.S., Trindade J.P.P., Rede de pesquisa participativa, a produção de conhecimentos e o desenvolvimento territorial, Bagé, Embrapa Pecuária Sul, 2011, 14-15 (in Portuguese)

[5] Costabeber J.A., Transição agroecológica - rumo à sustentabilidade, Agriculturas: Experiências em Agroecologia, AS-PTA, Rio de Janeiro, 2006, 3(3), 2-4 (in Portuguese)

[6] Fidalgo E.C.C., Pedreira B.C.C.G., Abreu M.B, Moura I.B., Godoy M.D.P., Uso e cobertura da terra na bacia hidrográfica do rio Guapi-Macacu, Embrapa Solos, Documentos,105, Rio de Janeiro, 2008 (in Portuguese)

[7] Freire P., Pedagogia do oprimido, Paz e Terra, Rio de Janeiro, 1987,39 (in Portuguese)

[8] Gliessman S.R., Agroecology, researching the basis for sustainable agriculture, New York, Verlang, 1997

[9] Grisel P.N., Assis R.L., Adoção de práticas agrícolas sustentáveis, estudo de caso de um sistema de produção hortícola familiar em ambiente de montanha, In: Cadernos de Ciência e Tecnologia, Brasília, 2012, 29(1), 149-156 (in Portuguese)

[10] SEAPEC, Agricultura Emergência - diagnóstico do impacto das chuvas nas áreas agrícolas da região serrana do estado do Rio de Janeiro, Secretaria de Estado de Agricultura e Pecuária, Projeto Desenvolvimento Rural Sustentável em Microbacias Hidrográficas do Estado do Rio de Janeiro - Rio Rural/BIRD, SEAPEC, Niterói, 2011, 13 (in Portuguese)

[11] Vygotsky L.S.A., Formação social da mente, São Paulo, Martins Fontes, 1999 (in Portuguese) 